\title{
A New Revised Definition of Contract Cheating
}

\author{
Shah Neyamat Ullah \\ School of Engineering and Technology \\ Central Queensland University \\ Gladstone Queensland, Australia \\ s.ullah@cqu.edu.au
}

\begin{abstract}
Contract cheating has appeared to become a global phenomenon, where students outsource their assignments to external third parties in the hope of obtaining better grades. The nature of contract cheating has changed over the years with current pervasive internet culture has made it much easier to cheat, hence there is a global rise in contract cheating activities. If unchecked, this poses a significant threat to the global higher education sector, where assessments are one of the established fundamental ways by which student learning is assessed. The purpose of this study is to critically review the existing Academic Integrity policies of Queensland, Australia public universities, as well as existing literature and document the contract cheating definition adopted. The review suggests a range of definition of contract cheating is available in the literature, with only three Queensland universities (out of seven in total) explicitly identifying and defining contract cheating in their policy documents. An evaluation of these definitions suggests that they miss out on important characteristics of cheating, such as cheating may occur without monetary transactions or even done by students' own friends and family members. In view of the above, a revised definition is presented, and its merit discussed.
\end{abstract}

Keywords - contract cheating, definition, authentic assessments, academic Integrity, higher education, policy

\section{INTRODUCTION}

Contract cheating generally refers to the situation when an assessment item is outsourced to a third party for solutionlater submitted for grading under the pretence of being the student's own work [1]. It is generally acknowledged that such cheating activities are on the rise $[2,3,4]$ and can potentially endanger the higher education sector around the world, where assessments are a primary way of student learning assessment and contribute towards the overall grade of a student. The severity of contract cheating is such that the Australian government is planning to ban advertising contract cheating services and making it a punishable offence (https://www.education.gov.au/tackling-contract-cheating).

However, there is a significant potential that banning such advertising services may motivate contract cheating service providers to work undercover, secretly operating through social media (for instance Twitter, Facebook), online chat services that allow sharing of data (eg. WhatsApp, Viber etc.) as well as use of virtual private networks (VPN) among students, bypassing internet traffic restrictions. Such clandestine operation through social media has been reported in several publications (see for instance, $[5,6]$ ).

Currently, with changing dynamics of the higher education sector; collaborative sharing economy [7], easy access to internet and data sharing websites, loss of human interaction through increased online teaching has created a fertile environment for contract cheating. Discussion on preventing methods of contract cheating is meaningful provided a definition of contract cheating is agreed upon.
This paper systematically reviews the existing literature on contract cheating and academic misconduct policies of Queensland Australia Universities in terms of the definition of contract cheating adopted and proposes an alternate improved definition.

\section{A. Objectives}

The objective of this paper is to critically evaluate the contract cheating definition adopted in the literature and academic misconduct policies of Queensland, Australia public universities.

\section{B. Research questions}

i) What is the current contract cheating definition available in the literature and adopted in various Australian public universities based in Queensland? ii) Is the currently adopted contract cheating definition adequate? If not, what is a more appropriate definition?

\section{EXPLORING THE RELATIONSHIP BETWEEN PLAGIARISM, CONTRACT CHEATING AND COLLUSION}

The UK Cambridge dictionary defines plagiarism as, "the process or practice of using another person's ideas or work and pretending that it is your own" [8]. The University of Oxford defines plagiarism more elaborately as, "plagiarism is presenting someone else's work or ideas as your own, with or without their consent, by incorporating it into your work without full acknowledgement. All published and unpublished material, whether in manuscript, printed or electronic form, is covered under this definition. Plagiarism may be intentional or reckless, or unintentional. Under the regulations for examinations, intentional or reckless plagiarism is a disciplinary offence" [9].

Eaton [10] presented plagiarism definitions adopted at various Canadian universities and conclude that plagiarism is discussed in a somewhat broader sense and at times include vague statements. This allows a wider interpretation and application of the definition, in turn making it easier for institutions to impose disciplinary measures against student committing academic misconduct [10]. This open interpretation and generalization preclude a deeper understanding of what plagiarism is and how it manifests in student work [10]. Louw [11] discuss the difficulties associated in defining plagiarism given the grey areas in establishing novelty, the extent of paraphrasing and difficulties associated with judging student ability to apply information. A widely accepted definition of plagiarism given in [12] and discussed in [13] is, "the intentional use of other people's words or ideas without due acknowledgement". 
Anecdotal experiences suggest that this latter simpler definition is popular and forms the perceptual understanding of the general public as well as university staff and students.

Based on the plagiarism definitions discussed above there is some overlap between the concepts of plagiarism and contract cheating, where not acknowledging the source is central to both these forms of academic dishonesty. Some commonalties between these two forms of academic misconducts have led to problems in defining them, where some define contract cheating as one form of plagiarism [14]. Walker and Townley [15] discuss that plagiarism involves a form of intellectual theft (Latin plagiarius, meaning kidnapper or seducer), where the original author is given no proper recognition. Whereas, in contract cheating, the original author colludes with the cheater, hence the theft aspect of plagiarism is removed in contract cheating. It needs to be noted that the detection of contract cheating is somewhat different than detecting plagiarism. While similarity matching software (such as Turnitin), can be used to infer plagiarism to an extent, detecting contract cheating is much more difficult and requires developing alternate detection criteria [5]. As noted above, the perception and definition of plagiarism are very much clear, at least to the general public. Moreover, outsourcing assessments to someone else for a solution (i.e. third party, friends or family members) is fundamental to contract cheating and not a necessary condition for plagiarism, assuming wide interpretation of plagiarism is not allowed, and the simpler definition is adopted. Due to these differences, it is prudent to define contract cheating separately and consider it a separate form of academic misconduct (AM) in student behavioural and university misconduct policies. This will benefit in raising social awareness of contract cheating and help tackle this growing problem.

Like plagiarism, there are debates on what constitutes unlawful collusion and what differentiates collusion from lawful collaboration [16-18]. In some literature, collusion is thought to be a variant of plagiarism despite obvious differences between them (see for instance, [19]). As Eaton [10] noted, such a broad definition only confuses staff and students alike. A popular definition of collusion, in agreement with public perception and adopted at several universities is: "form of cheating which occurs when people work together in a deceitful way to develop a submission for an assessment which has been restricted to individual effort" (see Latrobe University, [20]). Clearly, without wider interpretation of collusion, it fails to capture the essence and subtle variations of contract cheating discussed more elaborately later in the paper.

It is viewed that plagiarism, collusion and contract cheating all have distinct characteristics and falls under the umbrella term of academic cheating or academic dishonesty in general. Separate definitions of each will allow focus and clarity among all stakeholders (student, staff, university, third parties offering cheating services and the general public), therefore help in preventing such misconducts at higher education institutions as opposed to catch and punish.

\section{METHOD}

A systematic literature review was conducted to identify the different definitions adopted in the literature. Google Scholar, Google Search and EBSCO host Library (www.ebscohost.com) was utilised for article searching with search words of contract cheating, contract cheating definition, academic misconduct policy and contract cheating. The academic misconduct policy search was limited to Queensland Australia public universities. EBSCOhost was particularly chosen due to two large educational research databases, i) Education Research Complete (more than 2100 journals indexed) and ii) the Education Resource Information Center (ERIC). Some key definitions from the literature and academic misconduct policies are documented below.

\section{LITERATURE REVIEW: DEFINITION OF CONTRACT CHEATING}

The term contract cheating was first coined by Clarke and Lancaster [1]. They investigated the use of an online computer service provider RentACoder, providing computer programs in exchange of a fee to students and the general public. Contract cheating was defined as: the submission of work by students for academic credit which the students have paid contractors to write for them. Later, Lancaster and Clarke [21] defined contract cheating as: the type of academic misconduct where students outsource the production of coursework which they then submit to be assessed.

While the definitions are synonymous, the second definition explicitly treats contract cheating as academic misconduct (AM). Classifying contract cheating as academic misconduct is particularly important from a legal point of view. This allows universities to treat contract cheating as part of the student charter or academic misconduct policies, as opposed to referring the case to the court, which may be a very time-consuming process [22]. For instance, the Mytutor case in RMIT (Royal Melbourne Institute of Technology) took two years to resolve as well as staff time in preparation for court attendance [23].

Wallace and Newton [24] define contract cheating as: contract cheating is the process whereby students auction off the opportunity for others to complete assignments for them. Draper and Newton [22] suggest: contract cheating is a basic relationship between three actors; a student, their university, and a third party who completes assessments for the former to be submitted to the latter, but whose input is not permitted. 'Completes' in this case means that the third party makes a contribution to the work of the student, such that there is reasonable doubt as to whose work the assessment represents.

A more comprehensive definition was given recently in [25]. According to them contract cheating is defined as: where a student gets someone - a third party - to complete an assignment or an exam for them. This third party might be a friend, family member, fellow student or staff member who assists the student as a favour. It might be a pre-written assignment which has been obtained from an assignment 'mill'. The third party may also be a paid service, advertised locally or online. 
Several important aspects have been touched upon in the above definition. For instance, the third party may consist of friends and family members. The service provided might be just a favour without any payment involved or can be paid. Focus is also given to online contract cheating services, which under current pervasive internet culture appears to be a major contributor to contract cheating, where students are turning towards in vast numbers [3].

Some questions on the above-mentioned definition still arise; for instance, what if the student understands (both at a conceptual level as well as all the inner workings involved) all the workings involved, at a level that the student is confident in passing through any future interrogation and scrutiny on the workings. If an assignment consists of several questions or parts, what if contract cheating services are taken for only a fraction of the whole assignment? What if the student rewrites the assignment (a trick adopted to bypass plagiarism detecting services such as Turnitin) in his or her own words and then submit for grading?

\section{Australian University Policies on CONTRACT CHEATING}

In order to better understand the university policies on contract cheating and the contract cheating definition adopted, academic misconduct policies of seven Australian public universities based in Queensland were investigated. Table I outlines the definition, university name and the document reviewed.

\section{FINDINGS}

It is seen that three universities, QUT, CQU, USC explicitly identify and formally define contract cheating in their academic misconduct policies (Table I). Two universities JCU and GU have no mention of contract cheating in their policies. While University of Queensland (UQ) policy does not specifically define contract cheating but presenting others work as own has been identified under the umbrella term of cheating. On the other hand, The University of Southern Queensland (USQ) identifies contract cheating as academic misconduct but does not define it in the misconduct policy. CQU definition is strict and attempts made to contract cheat is considered misconduct. Summarising, the three definitions from above, they all lack important characteristics of contract cheating discussed previously. It is important to note that the academic misconduct policy is not the only mean of disseminating information on contract cheating. Some universities choose their news forum and on-campus students' groups to create awareness on contract cheating. However, it is deemed that a formal definition of contract cheating must be included in the academic misconduct policy and any student behavioural charter.

\section{DISCUSSION}

In view of the above definitions and limitations identified, a more elaborate definition is deemed necessary, where contract cheating definition should consider and answer common questions that higher education tertiary students may naturally have and therefore be more student-centric. A revised definition is presented as: Contract cheating is an academic misconduct, where students outsource their assignments or parts thereof to third parties; including family members and friends, either paid on unpaid, later submitting this assignment (or re-writing all or parts thereof) as their own work for grading with or without an understanding of the content.

It is important to classify contract cheating as academic misconduct and hence treated under the existing academic integrity policies of universities, which can be explicitly modified to tackle contract cheating. This is to minimise court appearances and wasting staff time. Similar to [25] definition, students may outsource the assessment to close relatives, family members and friends. This is a contentious issue and more research is warranted in identifying the extent to which family members and friends are permitted to help. It is viewed that family members are to act as teachers, discussing concepts and ideas and not solving the problem for the student.

The above definition captures the fact that the third party may be paid or unpaid and the work later is submitted for grading. It needs to be mentioned that, being unpaid does not necessarily violate the contract. Indeed, a social contract is still present irrespective of monetary transaction. An interesting question is what if the student understands all the workings obtained through contract cheating? The answer to this is tied with the learning outcomes of the unit, usually specified in the course unit profile. Even though the inner workings of the problem are understood, this undermines the research and effort required to solve a problem from scratch. The varied skills regarding contextual understanding, grasping textual information, understanding figures and illustrations, linking different parts of the problem and strategizing a solution methodology etc. are all missing and usually forms the learning outcomes of the course. Hence, the definition includes the phrase-with or without an understanding of content.

Some contract cheating companies suggest rewriting their provided solution to the student and then submit for grading [33]. This precludes skills and effort that might have been gained by trying to solve the problem by the student as discussed above. This is acknowledged in the definition by adding- re-writing all or parts thereof. Finally, the work must have been submitted for grading under the pretence of being a student's own work.

\section{VIII.LIMITATIONS AND RECOMMENDATIONS}

The study reviewed academic misconducting policies for only seven Australian universities and a brief review of the literature on contract cheating definitions. There is scope to further extend the work to all Australian universities as well as universities around the world. The paper reviewed only academic misconduct policies and student charters, other university forums and news articles focussed on contract cheating was not reviewed. In the absence of explicitly categorising contract cheating as academic misconduct, some universities may attribute contract cheating as a form of collusion, plagiarism and cheating in general to address student misconduct. It is believed that addressing contract cheating as a separate category of 
TABLE I. CONTRACT CHEATING DEFINITION ADOPTED AT SEVERAL QUEENSLAND UNIVERSITIES

\begin{tabular}{|c|c|c|c|}
\hline Definition & Institution & Remarks & Document title \\
\hline $\begin{array}{l}\text { Contract cheating is where a student arranges, } \\
\text { attempts to arrange, acquires, or allows any form of } \\
\text { paid or unpaid academic work (e.g. assessment, } \\
\text { exam, research) to be undertaken fully or partially by } \\
\text { a third party and the student represents or represented } \\
\text { the work as if it were their own. }\end{array}$ & $\begin{array}{l}\text { Central } \\
\text { Queensland } \\
\text { University } \\
\text { (CQU) }\end{array}$ & $\begin{array}{l}\text { Explicitly recognised as } \\
\text { academic misconduct. } \\
\text { Effective as of } 15 \text { July } \\
2019 .\end{array}$ & $\begin{array}{l}\text { Student Academic Integrity Policy } \\
\text { and Procedure; formerly known as } \\
\text { Academic Misconduct Policy. } \\
{[26]}\end{array}$ \\
\hline Contract cheating definition does not exist. & $\begin{array}{l}\text { James Cook } \\
\text { University } \\
\text { (JCU) }\end{array}$ & $\begin{array}{l}\text { Cheating classified as } \\
\text { academic misconduct. } \\
\text { Current as of July } 2019 \text {. }\end{array}$ & $\begin{array}{l}\text { Academic Misconduct Procedure. } \\
\text { [27] }\end{array}$ \\
\hline Contract cheating not identified. & $\begin{array}{l}\text { Griffith } \\
\text { University } \\
\text { (GU) }\end{array}$ & $\begin{array}{l}\text { Current as of April } 2015 . \\
\text { Next review in } 2020 .\end{array}$ & $\begin{array}{l}\text { Student Academic Misconduct Policy. } \\
\text { [28] }\end{array}$ \\
\hline $\begin{array}{l}\text { Contract cheating not explicitly defined, presenting } \\
\text { others work as student's own work acknowledged as } \\
\text { cheating; } \\
\text { cheating - occurs when a student acts before, during } \\
\text { or after an assessment or examination in such a way } \\
\text { as to seek to gain unfair advantage or assist another } \\
\text { student to do so and includes, but is not limited to - } \\
\text { (a) plagiarising the work of another person and } \\
\text { presenting that work as if it is the student's own work, } \\
\text { without appropriate acknowledgement. }\end{array}$ & $\begin{array}{l}\text { University of } \\
\text { Queensland } \\
\text { (UQ) }\end{array}$ & Current as July, 2018 & $\begin{array}{l}\text { Student Integrity and Misconduct. } \\
\text { [29] }\end{array}$ \\
\hline $\begin{array}{l}\text { Contract cheating involves a student engaging a third } \\
\text { party to complete assessment work on their behalf } \\
\text { and then representing the work as their own. It is } \\
\text { generally characterised by extensive use of the } \\
\text { supplied material, with limited additional input from } \\
\text { the student. }\end{array}$ & $\begin{array}{l}\text { Queensland } \\
\text { University of } \\
\text { Technology } \\
\text { (QUT) }\end{array}$ & $\begin{array}{l}\text { November } 2017 . \quad \text { Next } \\
\text { review November } 2020 .\end{array}$ & $\begin{array}{l}\text { C/5.3 Academic Integrity. } \\
{[30]}\end{array}$ \\
\hline $\begin{array}{l}\text { Contract cheating identified as AM but not defined. } \\
\text { Academic misconduct includes but is not limited to } \\
\text { collusion, plagiarism, contract cheating, } \\
\text { impersonation of a Student or University Employee, } \\
\text { and failure to comply with formal examination or } \\
\text { assessment instructions. }\end{array}$ & $\begin{array}{l}\text { University of } \\
\text { Southern } \\
\text { Queensland } \\
\text { (USQ) }\end{array}$ & $\begin{array}{l}\text { No specific date given, } \\
\text { accessed August } 2019 \text {. }\end{array}$ & $\begin{array}{l}\text { Academic Integrity Procedure. } \\
{[31]}\end{array}$ \\
\hline $\begin{array}{l}\text { When a student engages another party, whether paid } \\
\text { or unpaid, to produce an assessment piece on their } \\
\text { behalf. It could involve a student purchasing an } \\
\text { assessment item online, engaging an online company } \\
\text { to write a custom assessment piece, or asking a friend } \\
\text { or family member to produce their assessment piece. }\end{array}$ & $\begin{array}{l}\text { University of } \\
\text { Sunshine } \\
\text { Coast (USC) }\end{array}$ & May 2019. & $\begin{array}{l}\text { Student Academic Misconduct - } \\
\text { Procedures. } \\
\text { [32] }\end{array}$ \\
\hline
\end{tabular}

misconduct will help create social awareness and aid in minimising contract cheating.

\section{CONClusions}

This paper reviewed the existing definitions of contract cheating found in the literature and academic misconduct policies of Queensland Australia public universities. The current definitions were found to be incomplete and lack important details. Out of seven universities in total, only three universities were found to formally define contract cheating in their academic misconduct policies. In view of this, there is scope to improve these policies by including a concrete definition of contract cheating, clearly discerning it from academic misconducts of plagiarism and collusion. A revised definition of contract cheating was presented as: Contract cheating is an academic misconduct, where students outsource their assignments or parts thereof to third parties; including family members and friends, either paid on unpaid, later submitting this assignment (or re-writing all or parts thereof) as their own work for grading with or without an understanding of the content.

\section{ACKNOWLEDGEMENT}

The author acknowledges financial support from the School of Engineering and Technology, Central Queensland University.

\section{REFERENCES}

[1] Clarke, R., \& Lancaster, T. (2006). Eliminating the successor to plagiarism? Identifying the usage of contract cheating sites. In Proceedings of 2nd International Plagiarism Conference.

[2] Awdry, R., \& Newton, P. M. (2019). Staff views on commercial contract cheating in higher education: a survey study in Australia and the UK. Higher Education. doi:10.1007/s10734-019-00360-0

[3] Newton, P. M. (2018). How Common Is Commercial Contract Cheating in Higher Education and Is It Increasing? A Systematic Review. Frontiers in Education, 3(67). doi:10.3389/feduc.2018.00067

[4] Lines, L. (2016). Ghostwriters guaranteeing grades? The quality of online ghostwriting services available to tertiary students in Australia, 
Teaching in Higher Education, 21:8, 889-914, DOI: 10.1080/13562517.2016.1198759

[5] Dawson, P., \& Sutherland-Smith, W. (2019). Can training improve marker accuracy at detecting contract cheating? A multi-disciplinary pre-post study. Assessment \& Evaluation in Higher Education, 44(5), 715-725. doi: $10.1080 / 02602938.2018 .1531109$

[6] Amigud, A., \& Lancaster, T. (2019). 246 reasons to cheat: An analysis of students' reasons for seeking to outsource academic work. Computers \& Education, 134, 98-107. doi:https://doi.org/10.1016/j.compedu.2019.01.017

[7] Richardson, L. 2015. "Performing the Sharing Economy." Geoforum 67: 121-129. doi:10.1016/j.geoforum.2015.11.004.

[8] Dictionary UK Cambridge (2019): https:/dictionary.cambridge.org/dictionary/english/plagiarism

[9] Dictionary, Oxford (2019).

https://www.ox.ac.uk/students/academic/guidance/skills/plagiarism?w $\mathrm{ssl}=1$

[10] Eaton, S. E. (2017). Comparative Analysis of Institutional Policy Definitions of Plagiarism: A Pan-Canadian University Study. Interchange, 48(3), 271-281. doi:10.1007/s10780-017-9300-7

[11] Louw, H. (2017). Defining plagiarism: student and staff perceptions of a grey concept. South African Journal of Higher Education, Vol 31, Issue 5, pp. 116-135.

[12] Race, P. (2001) Assessment: A Guide for Sstudents (York: LTSN Generic Centre).

[13] Burkill, S. U. E., \& Abbey, C. (2004). Avoiding Plagiarism. Journal of Geography in Higher Education, 28(3), 439-446. doi:10.1080/0309826042000287009

[14] O'Malley, M., \& Roberts, T. S. (2012). Plagiarism on the rise? combating contract cheating in science courses. International Journal of Innovation in Science and Mathematics Education, 20(4)

[15] Walker, M., \& Townley, C. (2012). Contract cheating: a new challenge for academic honesty? Journal of Academic Ethics, 10(1), 27-44. doi:10.1007/s10805-012-9150-y

[16] Sutton, A., \& Taylor, D. (2011). Confusion about collusion: working together and academic integrity. Assessment \& Evaluation in Higher Education, 36(7), 831-841. doi:10.1080/02602938.2010.488797

[17] Sutherland-Smith, W.(2013). Crossing the line: Collusion or collaboration in university group work? Australian Universities Review, Vol. 55, Issue, 1,pp. 51-58.

[18] Velliaris, D.M. (2015). A clearer pathway to Institutionalising Academic Integrity: Distinguishing between collaboration and collusion

[19] Crook, C., \& Nixon, E. (2019). The social anatomy of 'collusion'. British Educational Research Journal, 45(2), 388-406. doi:10.1002/berj.3504
[20] LaTrobe University (2019). Academic Integrity. https://atrobe.libguides.com/c.php?g=414025\&p=4081479, accessed November 2019.

[21] Lancaster., T., and Clark., R. (2014). Using Turnitin as a Tool for Attribution in Cases of Contract Cheating. York: Higher Education Academy.

[22] Draper, M. J., \& Newton, P. M. (2017). A legal approach to tackling contract cheating? International Journal for Educational Integrity, 13(1), 11. doi:10.1007/s40979-017-0022-5

[23] Zobel, J. (2004). “Uni Cheats Racket”: A Case Study in Plagiarism Investigation'. In Proceedings of the Sixth Australasian Conference on Computing Education - Volume 30, 357-365. ACE '04.

[24] Wallace, M. \& Newton, P. (2014). Turnaround time and market capacity in contract cheating. Educational Studies, 40 (2), 233-236.

[25] Bretag, T., Harper, R., Burton, M., Ellis, C., Newton, P., Rozenberg, P., van Haeringen, K. (2018). Contract cheating: a survey of Australian university students. Studies in Higher Education, 1-20. doi:10.1080/03075079.2018.1462788

[26] CQU (2019) (Central Queensland University): Student academic integrity policy and procedure.

https://www.cqu.edu.au/policy?collection=policy\&form=policy\&quer $\mathrm{y}=$ Academic + Misconduct + Procedure \&sort $=$

[27] JCU (2019) James Cook University: Academic misconduct procedure. https://www.jcu.edu.au/policy/procedures/student-servicesprocedures/student-academic-misconduct-procedure

[28] GU (2019) Griffith University: Student academic misconduct policy https://policies.griffith.edu.au/pdf/Student\%20Academic\%20Miscond uct $\% 20$ Policy.pdf

[29] UQ (2019) (University of Queensland): Student Integrity and Misconduct.

https://ppl.app.uq.edu.au/content/3.60.04-student-integrity-andmisconduct

[30] QUT (2019) (Queensland University of Technology): Academic integrity. http://www.mopp.qut.edu.au/C/C 05 03.jsp

[31] USQ (2019) (University of Southern Queensland): Academic integrity procedure. https://policy.usq.edu.au/documents/14727PL

[32] USC (2019) (University of Sunshine Coast): Student academic misconduct -procedures. https://www.usc.edu.au/explore/policies-andprocedures/student-academic-misconduct-procedures

[33] Medway, D., Roper, S., \& Gillooly, L. (2018). Contract cheating in UK higher education: A covert investigation of essay mills. British Educational Research Journal, 44(3), 393-418. doi:10.1002/berj.3335 